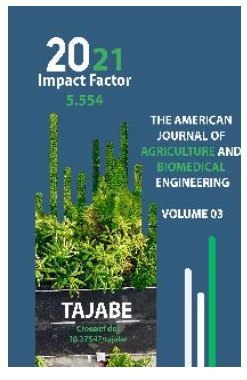

Journal Website: https://theamericanjou rnals.com/index.php/ta jabe

Copyright: Original content from this work may be used under the terms of the creative commons attributes 4.0 licence.

\section{Analysis Of International Experience In The Field Of Quality And Competitiveness Of Agricultural And Food Products}

\author{
Muminov Najmiddin Shamsiddinovich \\ Doctor Of Technical Sciences, Head Of The Department Of Standardization And Certification \\ Of Agricultural Products, Tashkent State Agrarian University, Tashkent, Uzbekistan
}

Kendjaev Anvar Akromovich

Master Of The Tashkent State Agrarian University, Tashkent, Uzbekistan

Abdirayimov Azizbek Ro'ziqul O'g'li

Assistant Of The Department Of Standardization And Certification Of Agricultural Products, Tashkent State Agrarian University, Tashkent, Uzbekistan

\title{
ABSTRACT
}

This article provides an analysis of the activities and international experience of countries in ensuring the quality and safety of agricultural and food products and their competitiveness. An analysis of the work carried out in the republic to ensure the quality and safety of agricultural and food products, raising them to a new level, is made, recommendations are given.

\section{KEYWORDS}

Chemical composition, toxicity, food quality, food competitiveness, food safety, international experience, certification.

\section{INTRODUCTION}

The results of reforms in the system of technical regulation, standardization, certification and metrology are periodically reviewed in the Republic of Uzbekistan. One of the recent meetings noted that in the republic it is necessary to cancel more than 5,000 outdated standards adopted before 1995, to bring the technical regulations on product quality and safety in line with the requirements of Europe and the EAEU. It is noted that in recent years, $43 \%$ of the country's standards have been brought underworld standards their total number has reached 12 thousand. The task is to bring the level of compliance with national standards by the end of 2021 - up to 21 thousand (75\%).

Proceeding from this, the achievement of the quality and competitiveness of food products 
is urgent, to provide the population of the country with full-fledged food products and increase their export potential. To increase the export volume, the products delivered to the world market must meet the requirements of international standards, norms and rules in all parameters and indicators.

\section{MATERIALS AND METHODS}

In the modern food industry, various methods of improving the quality of food products and improving the technological process are used.

It is considered that the most cost-effective is the use of food additives, as a result of which they have become widespread in most countries.

One of the ways to solve the food problem is the chemical synthesis of food products and their components. A qualitatively different direction of a possible solution to the food problem is the use of genetically modified (GM) products. The use of seeds of genetically modified plants significantly increases the yield.

The food contains more than 650 substances necessary for a normal life. Each of these substances takes its place in the chain of biochemical processes. $96 \%$ of organic and inorganic substances obtained from food have certain medicinal properties.

According to the World Health Organization (WHO), more than 500 thousand chemical compounds are used in industry, of which 40 thousand are harmful and 12 thousand are toxic. For many compounds, the maximum permissible levels of content are not established, including for food products.
In this regard, an urgent task is food quality control, the purpose of which is to protect the consumer from low-quality and dangerous products.

The analysis and study of international experience in ensuring the quality and competitiveness of food products in different regions and countries of the world seem relevant.

European legislation on food control. In 1920, the German Standards Institute (DIN) established a DIN compliance mark in Germany. In 1926, the official concept of "certification" appeared in England. Certification is mostly voluntary and is represented by several national systems. The largest of them is the British Standards Institute.

By a decree of 1938, a national certification system was established in France under the NF (French Standard) sign.

In 1952, the ISI Certification Marks Act was adopted in India. At the same time, the Canadian Organization for Standardization (CAS) was established in Canada. In the early 1960s, Denmark, Sweden, Norway and Finland created their regional system. Its activities are based on "Special Rules", national committees decide on the issues of awarding a product with a conformity mark.

Unlike Western Europe, the United States does not have uniform certification rules (a single national certification body). However, despite the absence of a single national certification body, attempts are being made to adopt common criteria for existing certification systems. 
When eliminating technical trade barriers, the world community strives to implement the principle "one standard, one test, one conformity assessment or tested once is accepted everywhere".

For this purpose, a national system of accreditation of testing laboratories has been created, and registration of certification systems is being organized. This principle is largely reflected in several provisions of the European Community (EU), the essence of which is a clear separation of mandatory and voluntary requirements for product quality indicators, harmonization of the requirements of standards, technical regulations, etc.

The legislation on food control in the EU countries has a three-level structure.

In the EU, the most important safety indicators for agricultural products and products of processing industries are defined in regulations and directives and are aimed at protecting public health, consumer interests (preventing falsification and fraud in the sale of food), protecting animals, plants and the environment.

In the EU countries, new directives are constantly being developed, lists of controlled substances are being finalized, the maximum permissible levels (MDUs) of their content in certain food products or raw materials are being established. The EU has developed and continues to improve the system of certification of agricultural products. For example, the decree "On ecological agriculture and the corresponding labelling of agricultural products and food products" defines the requirements for the production of environmentally friendly products. This standard assumes quality control at all stages of production, starting with raw materials. Today, it is impossible to sell agricultural and food products on the EU market without a proven quality and safety management system based on the principles of HACCP (Hazard Analysis and Critical Control Point, which means risk analysis and critical control points), which are a key element of the ISO 22000 families of international standards. Food production enterprises ensure the safety of their products and carry out their control. The functioning of the self-control system of enterprises is checked by the state body. EU food legislation ensures the free circulation of food and feed. Resolution (regulations) EC No. $178 / 2002$ of the European Parliament and the Council establishes:

- General principles and requirements for food safety;

- Procedures related to food safety;

- Obligations of participants related to food and feed at all stages of production and consumption;

- The responsibility for food products of organizations involved in the food chain, the basis of a rapid response system for notification of direct or indirect risks to human health, and also defines the European Coordinating Body for Food Safety.

The European Food Safety Authority is responsible for risk analysis (a mandatory procedure consisting of three elements: risk assessment (scientific advice and information analysis: hazard identification and description; exposure assessment; risk description); risk information exchange (about hazards and risks 
- professional competence, prevalence, transparency towards the consumer); risk management (legislation and supervision) - the formation of legislation in the $\mathrm{EU}$ and member states where food supervision is carried out by the FVO inspection in Dublin).

for food additives, seasonings, technological additives and materials in contact with food products

genetically modified organisms (GMOs)

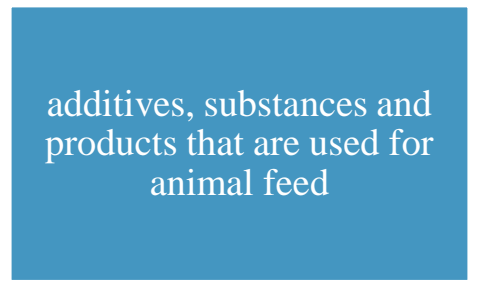

dietary products, dietary nutrition and allergens; biological risks

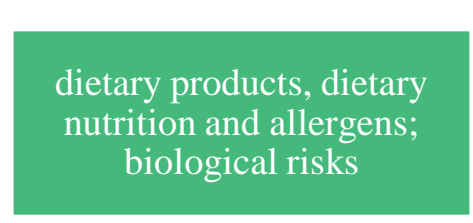

plant health and plant

protection products and their residues

nformation on control systems may be requested from third countries. The function of laboratory control is transferred to importing countries, subject to supervision by $\mathrm{EU}$ authorities (reference laboratories).
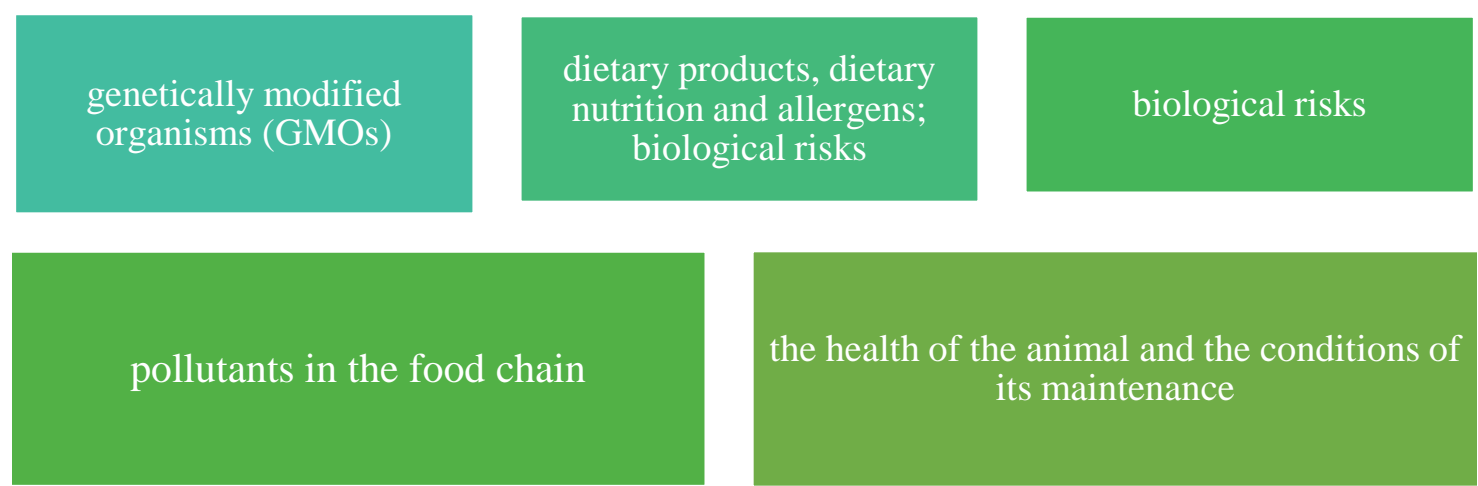

the health of the animal and the conditions of its maintenance

Figure 1. Information that the competent authority must delegate control functions to laboratories

The presence of such laboratories in importing countries is necessary to prove the continuity of control from the farm to Figure 1. The competent authority should transfer the control functions to laboratories that are functioning, evaluated and accredited in accordance with DIN EN ISO/IES17025.

The RASFF system (Rapid Alert System) is designed for the rapid exchange of information between states to protect the consumer from any, even potential, danger arising from the consumption of food products. The main objective of this system is to prevent the placement or withdrawal from the Community market of food products (or feed) that pose a significant risk to the health of the consumer.
The main groups of food products that require the creation and functioning of an alarm system are fish, meat, milk, fruits and vegetables, grains, nuts, spices, etc.

The reasons for the need for an alarm notification may be bacteria, mould, mycotoxins, heavy metals, organic environmental pollutants, pesticides, veterinary drugs, various additives found in food products that pose a risk to the health of the consumer.

Food quality Control in the United States of America. In the United States, food safety requirements are regulated both by federal law and at the state level. The main regulatory act 
at the federal level is the Law on Consumer Safety.

The United States has a stable and very effective system of quality control of food and medicines, taking into account safety requirements. The system is aimed at ensuring that agricultural products are produced using methods and substances that preserve the integrity of natural products.

The basis of this system is the US Food and Drug Administration (FDA).

The FDA performs supervisory functions, accredits independent expert laboratories and monitors their activities. The FDA is an independent body and is outside the sphere of influence of the federal ministries of Health and Agriculture.

To protect the consumer, the FDA sets maximum permissible concentrations of substances in food products and conducts frequent inspections of the so-called "market basket" when products are purchased in various regions of the United States and then analyzed. The FDA inspects incoming food imports.

Attention to quality and safety issues in the United States is currently being paid at all levels of the executive and legislative authorities, as well as by the public, a system of motivation has been created for food producers, including agricultural ones, to certify production, implement quality and safety management systems.

Considerable attention is paid to creating incentives for enterprises and organizations to produce high-quality and safe products for the domestic market. For example, enterprises that have not been certified according to the QS-9000 system (a quality standard based on the principles of international standards of the ISO 9000 series) cannot participate in a tender for receiving orders for the supply of products for state needs.

The use of chemicals by agricultural producers is severely restricted by law, the use of cytotoxic substances created based on carbon is completely prohibited.

In the United States, the National Organic Program (USDA) is being implemented, which contributes to the active development of the certification system for agricultural production. It is a system of normative acts, mechanisms and structures of their application. The regulatory framework is aimed at creating a quality control system at all stages of production, starting with raw materials (used feed, grain, etc.). For example, today there are more than 14.5 thousand standards in the WTO structure.

Thus, in the United States, a certain chain is being created that ensures the achievement of unconditional quality and safety of food products based on certification and control of land, raw materials, production, transport and trading companies and the product at the stage of production and sale. A distinctive feature of the food quality and safety regulation system in the United States is the involvement of independent expert companies with testing laboratories.

Food safety regulation system in Japan. Japan, which is sufficiently self-provided with rice, fruits, vegetables, and seafood, is heavily 
dependent on the supply of corn, cereals, and legumes, while rice consumption is constantly decreasing, giving way to imported goods.

Currently, the main exporter to Japan is the United States. They account for $23.9 \%$ of Japanese imports, the main part of which is agricultural goods.

The government document "The policy of providing the country with food" outlines the main goals of food security:

-maintain the level of self-provision of food, increasing production, and effectively use the resources available in Japan;

- Conclude a bilateral agreement with exporting countries, guaranteeing stable food supplies;

- Create a reserve of the most important agricultural products to prevent a crisis;

- Expand assistance to agriculture in developing countries to diversify sources of imports.

Japan's state policy in the field of food security is import-oriented and is primarily aimed at expanding the market of food suppliers and reducing the share of major importers in the total volume of supplies.

\section{CONCLUSION}

Thus, it can be concluded that the quality of manufactured products plays a special role in providing the population with food products and increasing the export potential in the food and processing industry.

It is known that the competitiveness of products is traditionally determined by several factors, such as the cost of production, operating costs, service, authority and status of the supplier. However, one of the main indicators of the products was and remains the high quality of the product offered.

Using the experience of the countries of the European Community, the United States and Japan will improve the state system of control and supervision of the quality and safety of agricultural products, eliminate inconsistencies with the regulatory requirements of the Republic of Uzbekistan to international standards.

Achieving high quality and ensuring the safety of products of the agro-industrial complex of the Republic of Uzbekistan, creating unified rules and requirements for producers of agricultural products and food products will greatly facilitate the task of promoting these products to the countries near and far abroad.

An important issue in the field of ensuring the quality and competitiveness of products is the updating and harmonization of the requirements and indicators of the national standards of the republic with the requirements of the standards of the international organization ISO and the standards of industrialized countries.

The analysis of the achievements and experience of the developed countries in ensuring the quality and safety of products dictates that production enterprises, taking into account the specific experience of the specialized enterprises of the advanced countries, need to develop measures for updating and harmonization, as well as for the introduction of international standards. 
Considering that the training of highly qualified specialists of higher education is the main factor in ensuring the quality and safety of food products by the Department of "Standardization and Certification of Agricultural Products" of the Tashkent State Agrarian University, Cooperation agreements have been concluded with the departments of the Uzstandart agency. In particular, the Research Institute of Standardization, Certification and Technical Regulation, the National Institute of Metrology, the Accreditation Center, the Republican Center for Scientific Testing and Quality Control ("UzTest" DUK), republican and foreign specialized departments of universities.

According to these agreements, planned research, scientific and methodological educational and organizational work is being carried out to improve state educational standards and curricula, to prepare textbooks and teaching aids.

\section{REFERENCES}

1. The Law of the Republic of Uzbekistan "On the quality and safety of food products".

2. The Law of the Republic of Uzbekistan "On certification of products and services".

3. The main legislative and regulatory documents of the Standardization and Certification System of the Republic of Uzbekistan.

4. The Law of the Republic of Uzbekistan. (2009). On technical regulation" of 23.04 .

5. GOST R 52173-2003. Raw materials and food products. Method for identification of genetically modified sources (GMO) of plant origin.

6. GOST 30178-96. Raw materials and food products. Atomic absorption method for the determination of toxic elements.

7. Guide to methods of analysis of food quality and safety/ed. I.M.Skurikhin, V.A.Tutelyana. M.: Brandes-Medicine, $341 \mathrm{p}$.

8. Eller K.I. (2004). Methods of quality control and food safety. Ros. chem. zhurn. No. 1.. P. 92-96.

9. Peasant Bulletin "USA guarantees the quality and safety of American food in Russia." 08.10.20016

10. Minchenko O.S. "Comparative analysis of the use of mechanisms for attracting experts and expert organizations in Russian and foreign practice." April 2014

11. Analytical Bulletin No. 8. "Actual problems of ensuring food security". 2018

12. A. Dernovich "Experience in Quality and Safety Assurance".

13. Obolkina V., Nagaitseva T., Kovalenko Y., Nemchenko J. "The US experience in creating a system of regulation and control of food safety." 